\title{
TTR
}

Traduction, terminologie, rédaction

\section{Valérie Bada, Céline Letawe, Christine Pagnoulle, Patricia Willson, eds. Impliciter, expliciter. L'intervention du traducteur. Liège, Presses Universitaires de Liège, 2018, 276 p.}

\section{Ellen Lambrechts}

Volume 32, numéro 2, 2e semestre 2019

URI : https://id.erudit.org/iderudit/1068910ar

DOI : https://doi.org/10.7202/1068910ar

Aller au sommaire du numéro

Éditeur(s)

Association canadienne de traductologie

ISSN

0835-8443 (imprimé)

1708-2188 (numérique)

Découvrir la revue

Citer ce compte rendu

Lambrechts, E. (2019). Compte rendu de [Valérie Bada, Céline Letawe, Christine Pagnoulle, Patricia Willson, eds. Impliciter, expliciter. L'intervention du traducteur. Liège, Presses Universitaires de Liège, 2018, 276 p.] TTR, 32(2), 243-247. https://doi.org/10.7202/1068910ar d'utilisation que vous pouvez consulter en ligne. 


\section{COMPTES RENDUS}

Valérie Bada, Céline Letawe, Christine Pagnoulle, Patricia Willson, eds. Impliciter, expliciter. L'intervention du traducteur. Liège, Presses Universitaires de Liège, 2018, 276 p.

Theories within translation studies range from the notion that everything is translatable to the notion that translation is impossible. In response to this ongoing debate, Impliciter, expliciter. L'intervention $d u$ traducteur provides a broad range of approaches to translation. Edited by Valérie Bada, Céline Letawe, Christine Pagnoulle, and Patricia Willson, the book sets out to survey the interventions made by translators to overcome the cultural obstacles in translation. By focusing on occurrences of explicitation and implicitation, it provides answers to questions like: Is the translator always tasked with rendering the original's essential meaning? If the translator recreates the original in a new time and setting, why not assume that the resulting work has a different purpose? How can a divergence in perspective be traced through the words that are used? (p. 8).

Impliciter, expliciter begins with a chapter by Lance Hewson. The author encourages scholars in translation studies to be critical of Blum-Kulka's "explicitation hypothesis," which states that explicitation is an inherent part of the translation process (p.15). He makes the point by adopting Becher's arguments (2010) and demonstrating that explicitation is not a universal of translation but rather the result of the translator's individual decisions. Hewson proposes to abandon the concept of translation universals and to focus instead on the effect of translatorial interventions. For Hewson, the prevailing descriptive nature of current research in translation studies and increasing use of computer-based tools are problematic. Typically, these realities fail to take into consideration the variables at play, such as the environment in which the translation takes place, and their subsequent implications. In order to resolve this situation, he develops an approach of his own, a restrictive one, which concentrates on small-scale analyses of corpuses. These are limited to a narrow range of high-quality translations, which, in turn, form a coherent whole in terms of authorship, translatorship, or period.

In the second theoretical chapter, Christiane Nord addresses the referential function of translation. Her central argument is that translators adapt the degree of explicitness of their texts according 
to the presupposed knowledge of the target readers. Translated texts, like other textual works, require a proper distribution between implied and explicit information. Explicitation is needed to clarify content that is assumed to be unknown to the target audience, whereas implicitation occurs when the target readers are already familiar with the reality described. This brings Nord to the conclusion that explicitation is appropriate for (linguistic, encyclopaedic, and pragmatic) presuppositions about the source culture or a third culture, and implicitation for (linguistic, encyclopaedic, and pragmatic) presuppositions about the target culture.

The remaining chapters are organized around case studies, but they all revolve around the theoretical debate on explicitation and implicitation initiated by Hewson and Nord. The case studies are grouped according to the following areas: "artistic productions," "economic and political challenges," and "didactic reflections."

Four chapters focus on literary and cinematographic productions. In "Quand la théologie s'en mêle: première traduction française de Paradise Lost de John Milton," Christophe Tournu provides a comparative analysis of this biblical epic and its first translation into French. As Tournu illustrates, Dupré de Saint-Maur's version presents considerable discrepancies from the original text, which, contrary to what the translator himself claims in his preface, cannot be justified by the "génie différent des langues" (p. 59). Paradise Lost had in fact been adapted to the expectations of the Catholic target audience in order to ensure that the book contained nothing heretical. By ending with a comparison of Dupré de Saint-Maur's translation and the second French translation made by Racine, Tournu finds a clever way to show how embedded a translation is in its context and to what degree translators practice self-censorship. In "Traduire l'écriture des confins chez Sapphire: entre trop-dit et non-dit," Karen Bruneaud raises the hypothesis that the more complex a text is, the greater the temptation to make it more explicit (p. 87). In order to test this hypothesis, Bruneaud analyses Push, a novel about an illiterate Afro-American girl, which can be considered complex due to its provocative content, and its linguistic and stylistic peculiarities. Relying on Candace Séguinot's classification, which distinguishes three degrees of explicitation (p. 87), Bruneaud shows that Push's translator has resisted the urge to make the original discourse more accessible to the target audience. However, the choices made by the 
translator result in losses, such as the protagonist's vernacular and her corresponding sociocultural identity. Sabrina Baldo de Brébisson, then, examines how translators proceed when they come across a term that has no equivalent. While the word "prefect" that has no lexical equivalent in French because of its rootedness in English society serves the purpose well, the "Étude d'un culturème intraduisible et de sa traduction plus ou moins équilibrée" seems to be intended primarily to carry a didactic message. Indeed, the study of the ways in which "prefect" appears in the French versions of the realistic novel Lord of the Flies, the magical book Harry Potter and the Philosopher's Stone and the film Another Country leads the author to affirm that even culturemes are translatable, and that a good translator is one who combines technical procedures (such as explicitation) with creativity. In "Implicitation and Explicitation in Film Translation: Inseparable Twins," Sarah Cummins and Adriana Şerban argue that subtitles are characterized by a constant alternation of explicitation and implicitation. They support this idea with evidence from The Mission and The Piano, two films in which language plays an important role. By zooming in on the scenes where English is used alongside indigenous languages or sign language, the authors demonstrate how explicitation and implicitation work together, "sometimes inviting viewers to fill in gaps, sometimes subtly directing their attention and engagement, sometimes merely supplying a weft to support the soundtrack's warp" (p. 139).

The next section explores the societal challenges translators face when opting for explicitation or implicitation. Alessandra Rollo looks at "Les enjeux de la traduction économique français-italienfrançais: choix traductologiques et stratégies mises en œuvre." Although repetitive at times, this chapter provides a useful overview of the difficulties that occur when translating acronyms and metaphoric expressions for professional use. The following chapter focuses on "Les noms de marques en traduction: entre implicitation obligée et explicitation obligatoire." Fabrice Antoine contributes to this understudied research area by developing a practical guide for translating brand names. Instead of opting for one of the two extremes that are "obliged implicitation" (the erasure of all brand names) and "obligatory explicitation" (the replacement of a brand name by a paraphrase), he proposes an intermediary strategy, maintaining the foreignness of the original word, while making explicit all the features 
that are necessary to convey its significance. Héba Medhat-Lecocq makes clear that translating cultural references becomes a particularly delicate process when politically charged ideas are involved. Using well-chosen examples, the author of "Traduire la révolution égyptienne. Vers une démarche interculturelle de la traduction" demonstrates that translation often surpasses the limits of mediation and even includes a negotiation exercise wherein the translator tries to compensate for the losses that occur in intercultural communication. In the same vein, Christina Schäffner examines "Politically Sensitive Texts in Translation." As she illustrates by means of extracts from news websites, journalistic discourse that involves translation raises ethical questions, because the strategies of journalists do not always align with the values that are fundamental to translator practices.

In the last section, the focus shifts towards didactic discussions on explicitation and implicitation. On the one hand, in "Développer les compétences inférentielles des étudiants en traduction," Margrethe Lykke Eriksen brings Wilson and Sperber's relevance theory and Toulmin's argumentation model together in a tool that promotes the explicitation of implicit argumentative structures. Céline Letawe and Vera Viehöver, on the other hand, try to raise students' awareness of the implicit political orientation of certain (German) words in "Les enjeux de l'implicite politique en traduction. Réflexions à partir d'une séquence didactique." Interestingly, they point out that such associations may arise in the source as well as in the target culture. This section ends with a republication of a text written in 1984 by Jean-René Ladmiral, who seeks to "rationalize" the choices that he made while translating Adorno's Minima Moralia. Although the editors justify the presence of his chapter in the volume by referring to a seminar that the author gave in 2014 at the University of Liège, it seems incongruent with the previous chapters and the didactic purpose of the section. Ladmiral's description of the procedure he followed is very meticulous, but so technical and filled with jargon that it requires specialized knowledge to be understood.

Impliciter, expliciter demonstrates, as announced in its introduction, that the translator is an "équilibriste culturel" [cultural equilibrist] (p. 12). The cases of explicitation and implicitation presented in this book allow one to trace the translator's interventions and the subsequent diverse implications. The book is, therefore, of great interest to translation studies scholars, but also to students and translators-to- 
be. However, its true merit lies in the variety of perspectives it brings together. By combining a theoretical focus with attention to specific artistic, economic, political, and didactic needs, the volume manages to shed new light on a much-discussed subject.

Ellen Lambrechts

KU LeUven

$* * * * * * * * * *$

\section{Marie-Alice Belle et Álvaro Echeverri, études réunies par. Pour une interdisciplinarité réciproque. Recherches actuelles en traductologie. Arras, Artois Presses Université, 2017, 208 p.}

Pour une interdisciplinarité réciproque est le $42^{\mathrm{e}}$ volume de la collection «Traductologie», lancée en 1997 chez Artois Presses Université avec le titre ambitieux et séduisant d'Anthony Pym Pour une éthique $d u$ traducteur. Vingt ans plus tard, la quatrième de couverture des études réunies par Marie-Alice Belle et Álvaro Echeverri promet de «nouvelles pistes théoriques et méthodologiques mettant en valeur la contribution actuelle et potentielle de la [traductologie] aux autres domaines de recherche en sciences humaines». Le volume est né du colloque «Repenser la place de la traductologie dans les sciences humaines : vers une interdisciplinarité réciproque» tenu à Montréal en mai 2012 à l'occasion du 80 congrès de l'Association francophone pour le savoir (Acfas). La décision de remplacer la préposition vers qui figurait dans le titre du colloque par la préposition pour dans le titre du livre traduit la volonté de faire de ce dernier un plaidoyer.

Le constat de Roch Duval, un des contributeurs, est clair : «La traductologie vit des heures difficiles ces derniers temps» (p. 46). En effet, après sêtre définie en tant que discipline en se distinguant de la linguistique d'une part et des études littéraires de l'autre, la traductologie a connu au cours des dernières décennies un «tournant» interdisciplinaire qui a entraîné un véritable boom, mais également un certain flou conceptuel lié à une ouverture toujours plus grande. La discipline a certes profité de nombreuses importations méthodologiques et théoriques (on parlera, avec Klaus Kaindl, d'«interdisciplinarité instrumentale», p. 49) qu'il s'agirait d'approfondir et surtout d'articuler, mais elle n'est hélas pas parvenue à exporter grand-chose (la fameuse interdisciplinarité réciproque du titre, celle qui serait «souhaitable pour consolider la discipline» (p. 25) comme l'indique Nayelli Castro). 